\title{
Holistic Health Model Of Sustainable Development
}

\author{
Annamaria Mato-Juhasz, Assistant Prof.
}

Department of Theoretical Health Science, Faculty of Health Care, University of Miskolc, Hungary

Emoke Kiss-Toth, PhD, College Prof.

Institute Leader, Dean, Department of Preventive Health Care, Faculty of Health Care, University of Miskolc, Hungary

Krisztina Szegedi, PhD, Associate Prof.

Department of Business Enterprises, University of Miskolc, Hungary

doi: 10.19044/esj.2016.v12n21p227 URL:http://dx.doi.org/10.19044/esj.2016.v12n21p227

\begin{abstract}
Health can be interpreted not only as an important element of sustainable development. It is connected to its all the three pillars namely its environmental, economic and social dimension as well. Health can be found directly or indirectly in every goal related to sustainable development. Considering the importance of health, the aim of our research was to elaborate a holistic health conscious model encouraging sustainable development. Holistic health conscious model means a model including the physical, psychical and mental health of the individual. Furthermore, besides the responsibility of the individual environmental effects are also taken into account as well as the intervening factors. In addition, it integrates the aspect of sustainable development. In our research, first of all we were looking for the answer to the following (1) what kind of stakeholders play a role in developing health consciousness? (2) What is the role of individuals, the state, the companies and NGOs in developing health consciousness? The article presents the holistic health model which was created as a result of the empirical research.
\end{abstract}

Key Words: sustainable development, health consciousness, holistic health, corporate social responsibility

\section{Introduction}

Health is the origin and also the result of sustainable development. Additionally, it is an important indicator for achieving the goals of sustainable development. (Sustainable Development Solutions Network, 2014; World Health Organization, 2016). One of the goals of sustainable 
development accepted by the UN in 2015 is good health and well being handled as one. In addition, the proposals of sustainable development emphasize that health improvement can be accomplished based on the adjusted initiations of several characters and sectors (e.g. Sustainable Development Solutions Network, 2014).

In order to create a holistic health model which is in harmony with sustainable development we were looking for the answer to the following questions: what kind of stakeholders play a role in developing health consciousness? What is the role of individuals, the state, companies and NGOs in developing health consciousness? In the first part of the article the main conclusions of the related special literature are summarized then the main results of our empirical research can be found. The main conclusions of the research are included in the summary.

\section{The connection between sustainable development and health}

Health was defined by the World Health Organization in the mid 1900s as the following: "Health is a state of complete physical, mental and social well-being and not merely the absence of disease or infirmity." (World Health Organization, 1948). Health is valuable as itself what is more it is one of the most basic human rights. It is also the source and results of sustainable development. (World Health Organization, 2016).

In connection with sustainable development in the last few decades it was less emphasized its complex correlation with health. It is so, in spite of the fact that in 1972 the UN conference about human environment revealed that damage on nature caused by men has negative effects on people's physical, mental and social health (United Nations, 1972). For sustainable development it is essential to develop health extensively, as it is "the foundation of human welfare and productivity" (World Commission on Environment and Development 1987, p. 93). The idea that men have the right to healthy life (United Nations, 1992, basic principle 1) established the confirmation of the role of health regarding sustainable development (UN System Task Team, 2012; WHO, 2016). The Rio+ conference in 2012 revealed that "... health is a precondition for and an outcome and indicator of all three dimensions of sustainable development." Developing health is necessary to implement a receptive, fair, economically productive and healthy society (United Nations General Assembly, 2012, p. 27).

The UN defined the main goals of sustainable development in September, 2015 in a meeting about Sustainable Development. For each agegroup regarding healthy life and well-being the following goals were set: decreasing the number of deaths of mothers, new-born babies and children, stopping serious diseases like AIDS, tuberculosis and malaria as well as fighting against hepatitis and other infectious diseases. The number of deaths 
caused by dangerous chemicals from air, water and soil pollution as well as pollution has to be decreased significantly. Encouraging mental health and well-being, the prevention of addictions and confirming their treatment including drug addiction, harmful alcohol consumption and smoking also came into the limelight. Another important goal is to place universal health service into operation, the access to essential qualitative health services furthermore access to safe, effective, qualitative and affordable medicines and vaccinations for everyone (United Nations General Assembly, 2015).

The goals of sustainable development cannot be achieved in case of frequent serious diseases as it hinders economic development and poverty alleviation. Nevertheless, people's health cannot be sustained without healthy environment, healthy diet and lifestyle habits, responsible health service system and the proper management of natural resources. At the same time health has a positive effect on economic and social development. Particularly in developing countries it contributes to the increase of gender equality just as to social solidarity but directly or indirectly it contributes to all the 17 goals of sustainable development defined in 2015. Consequently, health since it has a complex connection to sustainable development can be considered as the central element of sustainable development (Sustainable Development Solutions Network, 2014; World Health Organisation, 2016; Every Women Every Child, 2015).

\section{The Models of Health Conscious Behaviour}

Health conscious people are aware of their own well-being and are motivated to sustain their quality of life or improve that with pursuing healthy behaviour (Newsom et al., 2005). Health consciousness is "the responsibility taken by men for themselves in order to preserve good health which requires that we should take care of our good general state of health, our physical-mental and relationship balance" (Bagdy, 2010, p. 6.).

Health conscious behaviour models describe the factors influencing health of the individuals. Researches related to this are also looking for the intervening points and often focus on the fact whether the individual has the responsibility for their own health and quality of life and if it is so, what kind and to what extent.

"The individual's general state of health is determined by several factors: (1) the inherited, (2) the acquired physical-psychical qualities, (3) the given individual's self-concept and world-concept." (Nemzeti Egészségfejlesztési Intézet, 2015) The physical, psychical-mental and social dimensions can be found in several health conscious models.

Among the factors determining health the most frequently mentioned ones are genetic and external factors, lifestyle, the effects of social environment and the connections of health service are stressed (Pikó, 2006). 
Based on the declaration of Jakarta, health can be described as the correlation of external environmental factors, personal behaviour factors and host factors (Nagy \& Barabás, 2011). The level of health consciousness is influenced by (1) internal factors: family size, gender, school qualification; (2) external factors: the media, place of living, environmental effects; (3) motivation factors: education, free time, being informed. The most determining factors of health conscious behaviour are: healthy diet, physical training - exercising, going to check-ups (Szántó, 2008).

Further important factors of health conscious behaviour are the exclusion of harmful addictions, taking care of psychical health, calm lifestyle, avoiding stress, healthy sexuality, vaccinations, food supplements, vitamins, treating diseases (Emberi Erőforrások Minisztériuma, 2014).

According to the American Holistic Health Institute our health is determined by our lifestyle in 53\%, our inherited qualities in $18 \%$, our environment in $19 \%$ and the health supply system in $10 \%$ (Walter, 2016).

\section{The Holistic Health Conscious Model}

The central element of our holistic health conscious model is the holistic health condition which is affected by supportive and hindering impacts from the macro environment of health as well as from the active stakeholder who the individual has contact with (Figure 1).

\section{Holistic Health Condition}

Acknowledging Hidvégi et al. (2015) definition of health, the holistic health condition describes the momentary condition of the physicalpsychical-mental and social relationships.

The momentary condition of the body is interpreted as a current physical condition. Physical diseases can be the consequence of psychic problems (Dahlke, 2011). Based on this in the model we declare that physical symptoms act as a signalling system providing information about our physical condition. Non-perceptible physical symptoms can be identified with screening examinations. 
Figure 1. The Original Model of Holistic Health Consciousness

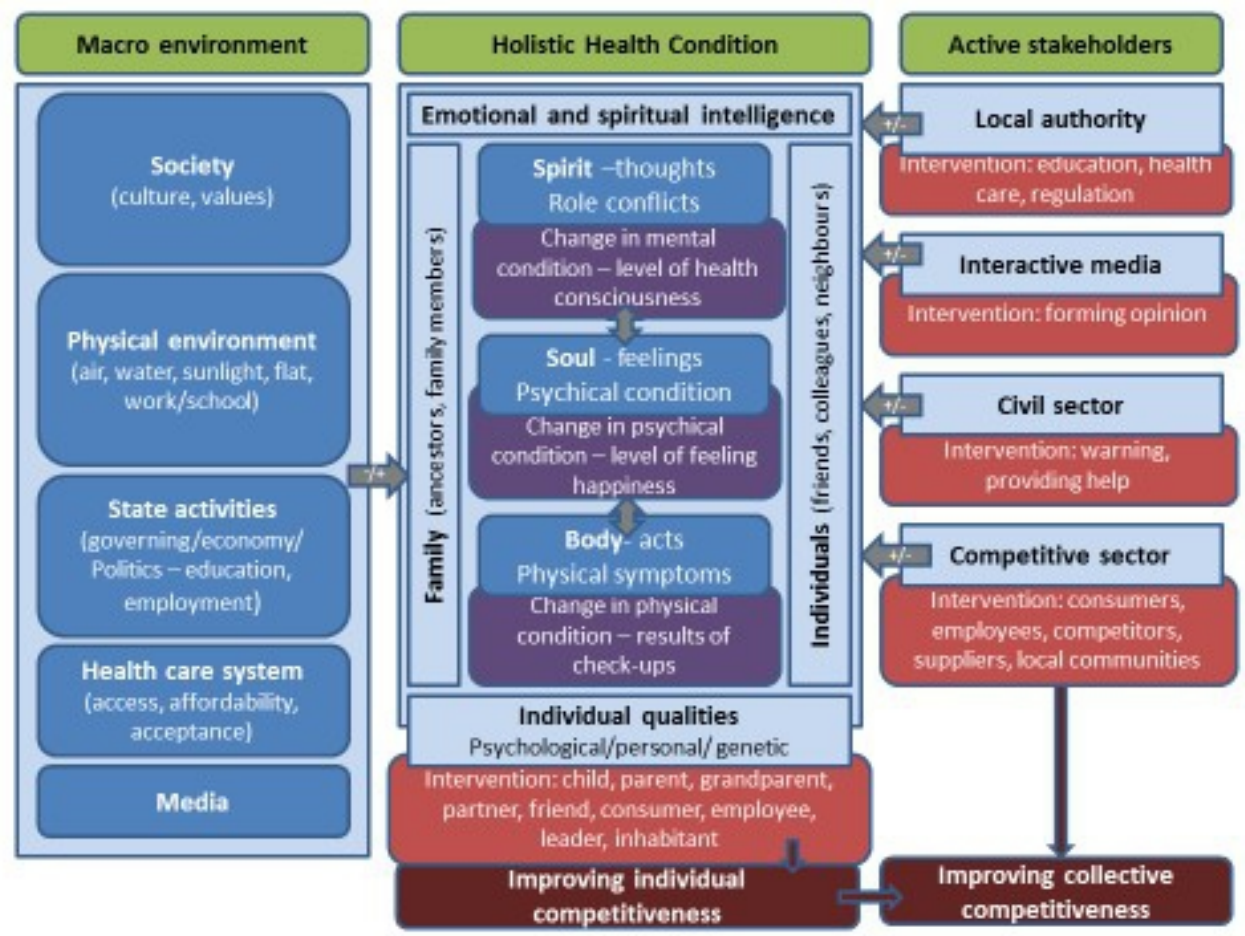

Source: Our research

The momentary psychical condition can be described as a set of feelings in us in the given moment. The scientific area of positive psychology focuses on positive feelings (the individual is satisfied with the past, happy at present and has hopes about the future), on the positive individual characteristics (the strengths and virtues of the individual) and the positive institutions (examples of the human community) (Bagdy, 2015).

The momentary mental health condition is defined as the total amount of actual thoughts. The scientific area of social psychology defines quite precisely the roles of individuals in the society, also the process of learning their role and their role conflicts (Csepeli, 2014). In our original model we rely on these grounds of social psychology just as on the concept of health by Hidvégi et al. (2015). The increasing tendency of mental diseases makes it reasonable that it appears in the model and thus it is dealt with in health strategies and systems (e.g. Frasheri \& Dhamo, 2016).

Social psychology deals with social relationships and also with the effects of them on individuals. Cooperation and trust are the fundamental terms needed to improve quality of life and health (Kopp \& Martos, 2011). In our original model the quality of current social relationships - namely relationship with the family, friends, colleagues and neighbours - is affected 
on the one hand by the current condition of the balance of the holistic threecomponent health. While, on the other hand it is also influenced by the responsibility taken by the individual for their own life, decisions and acts. At the same time the quality of social relationships also influences the health of the individual since in the course of socialization these people show models for way of thinking, emotional models and models of action.

The significant element of holistic health condition is the responsibility of the individual. The responsibility of the individual extends to lifestyle and the different factors of health preservation which might also affect physical, psychical and mental health. We find it important that a part of this is the responsibility taken in the different roles of the individual. As a private person the individual has influence on other people's health as a partner, as a parent, as a friend and as a member of the local community. As an employee the health conscious behaviour is also important, which means on the one hand obeying health care rules, the expectation of the healthy work environment and tasks which do not harm health on the other hand that the individual's commitment to work would not lead to damaging health (e.g. workaholism, burnout). Above all this, the individual as a consumer has an important role as well. Thus, health conscious behaviour also means a kind of responsible consumption since the enhancing consumer society might bring about damaging health.

\section{The Macro Environment of Health}

When creating the model, we started from the fact that there are several macro environmental factors with supportive and harmful effects on the individual's health. Among the environmental factors affecting health we can find physical environment, the media, health environment, economic environment, psychosocial environment just as social-political environment (Nemzeti Egészségfejlesztési Intézet, 2015). Based on them we defined 5 factors.

One of the most essential factors is the society which represents the values and culture of the given medium. These permeate into the individual's conscious and subconscious part during socialization thus forming the individual's way of thinking, emotional reactions, decisions and acts. The more extensively the given society represents the individual's responsibility, the larger the possibility of creating and maintaining the individual's holistic health due to being able to balance the different segments.

The next important factor which has a large effect on the the individual's health is the physical environment itself; the quality of air, the quality of and access to drinking water, the degree of sunlight, living conditions, school and working conditions. The cleaner and more comfortable they are, the more positive effects they have on the individual's health particularly on 
physical health however it is well-known that fresh air and sunlight also affect psychical and mental health.

Apart from all these factors, concerning individual's health, the state and its activities are also determining factors. Politics and the areas of the government belong to this set since they greatly determine individual's possibilities. The economic operation and performance clearly influence the individual's income hereby future prospects. The education system affects the way of thinking, general knowledge and emotional intelligence as well as mechanism of decision making and acts hereby the education system definitely influences psychical and mental health.

The health system is closely linked with the activities of the state however due to its effect on health particularly on physical health it is mentioned as a separate category. The access to health supply system, how affordable the services are and the extent of the acceptance of the system might be a question of life and death.

Nowadays the media has a greatly influential effect. It transmits the actual norm, which is even more complex than ever before due to globalization. In these days the Internet provides several possibilities to seek information about health (e.g. McKinley, 2014) thus it has a significant effect on health consciousness as well.

\section{Active stakeholders}

The model contains those stakeholders as well, who as intervening active stakeholders have impact on the individual's health thus such conscious actions can be linked to stakeholders as active stakeholders which support individual's health.

Developing health can be carried out with tuned efforts of the different sectors as several common factors connect health with environment protection, agriculture, food industry, water - and energy management, city development, transport, investment and communication (Sustainable Development Solutions Network, 2014).

From health point of view stakeholder is the local authority which can become an intervening active stakeholder with local health care and health developing regulation and further local intiatives. The local authorities have particularly important role in the developing countries (Idike, 2014). The media and within that the social media can become an intervening active stakeholder with enhancing health consciousness. Drawing attention to the possibilities of health preservation as well as opinions on positive acceptance of health preservation may also belong here. The civil sector with its different activities contributing to forming attitude and providing help can become an intervening active stakeholder. It can draw attention to practices which cause unsustainable social and environmental processes furthermore it 
can draw up and carry out suggestions related to health preservation.

The business sphere can turn into a very significant intervening active stakeholder particularly based on its corporate social responsibility, in case of providing healthy products and services for customers, ensuring cafeteria system to the employees, organizing and broadcasting cultural programs, ensuring working conditions which preserve health, strengthening the feeling of self-esteem, ensuring health preservation and recreation possibilities.

The long term effects of health development at work can emerge if they mean not only a campaign but they become part of company operation (Szolnoki \& Berényi, 2016). Moreover, the companies have the possibility, unlike their competitors, to position themselves on health preservation. In addition, for the suppliers they can draw up regulations regarding health preservation and provide local communities with health preservation programs and possibilities.

In the model the basis was that health affects competitiveness on individual and community level as well. The researches prove that there exists a connection between health and productive economy on individual and social level too. The reason for that is diseases cause cost and profit is not produced, however developing health condition increases productivity, the participation in education and savings as well (Kollányi, 2013).

The holistic health conscious and responsibility model is a holistic type from several points of view. Firstly, it starts from the harmony of bodypsyche-spirit on the level of the individual. Thus health condition is interpreted as the continuous balancing of this three-component unit so it means the succession of momentary conditions. Secondly, the model is holistic because it contains those social stakeholders which are able to influence individual's health, furthermore capable of intervening and this way becoming a social active stakeholder. Thirdly, it is holistic since it integrates the concept of health of sustainable development, namely it considers health as one of the starting points of sustainable development. On the other hand, it is regarded as a result of sustainable development.

\section{Empirical research}

In our empirical research we saw the previously described model and its elements as a hypothesis. The aim of our research was to test the holistic health conscious model which encourages sustainable development. In the course of the research we wanted to answer to the question that what stakeholders play roles in developing health consciousness? What is the role of the individual, the state, companies and NGOs in developing health consciousness?

In order to test our original model in April, 2016 we made 10 depth interviews with the representatives of the stakeholders who were described in 
the model. Depth interview is a qualitative procedure made in private, which makes it possible to get familiar with the deepest motivation, subconscious motives and feelings of the respondent (Stokes \& Bergin, 2006). The interviewees were chosen with respect to having a representative from each group of stakeholders described in the model. Among the interviewees there was a person providing services to improve general state of health, a journalist, a health trainer, a social pedagogist, a health organizer, two representatives from NGOs, two associate professors from the faculty of health and a pedagogist. Table 1. summarizes the suggestions by specialists made in depth interviews.

Table 1. The suggestions of specialists to improve health conscious model Suggestions of the specialists

Family means the unit of people living in the same household. They should be separated more in the model.

It would be a good idea to supplement state activities with: education, employment, social protection. The categories Family and Individuals should be emphasized more. Instead of individual responsibility individual abilities should be used in the model, which can be natural and learned. Apart from that it is determined by genetics as well. In order to see the system, the following phrases should be written: spiritual intelligence and emotional intelligence because this way it can be learned and measured. Education should be emphasized more; the seniors appear as mentors who might be samples. The competitive sector can be divided into financial and private sector.

It would be a good idea to change the macro environment sequence: physical, society, media, state and health system. In case of stakeholders, instead of media, social media would be better because that is an undertaken opinion. Or it can also be a private and a commercial category division, but it is important to distinguish the two categories. Concerning the psychical category there is a huge backwardness related to feelings, IQ can be learned and measured and it should be shown. Instead of individual ability (genetics, psychology and physical environment) individual determinants would be better to use.

Those people should also be given help who operate well, who are healthy. The sector of tourism can have an important role in it. It is worthwhile to show it in the model.

The Church is important because of schools; they should also be involved in the Figure. Instead of competitive sector it suggests characters of the economy.

The Church is necessary at stakeholders. Social supply must be involved in the local authority. The environmental block from down to upward: physical, health system, state, society. The media as a filter can be vertical in the picture representation.

The family and the individuals can be in the same category. There can be arrows forward and backwards as the effects are also of this kind.

Emotional intelligence can be involved in mental health. The civil sector is also good at conveying knowledge thus it can intervene.

In Gatekeeper function there are two categories: the values and the family. In case of the competitive sector also the activities should be listed and not the roles.

Education must be given a greater emphasis in the model.

Source: Our research

In most cases the information given during the interview was built into the model. Among the intervening active stakeholders, we involved the 
Church too. The individuals who have influence on the individual got into one category. Between this group and the macro environment the category called society has been defined as a distinguished category because of their gatekeeper function. Within state activities education got the first place. Examining the responsibility of the individual and the competitive sector from intervening point of view roles came to the front and not the activities. The modified model is shown in Figure 2.

Figure 2. The Modified Model of Holistic Health Consciousness

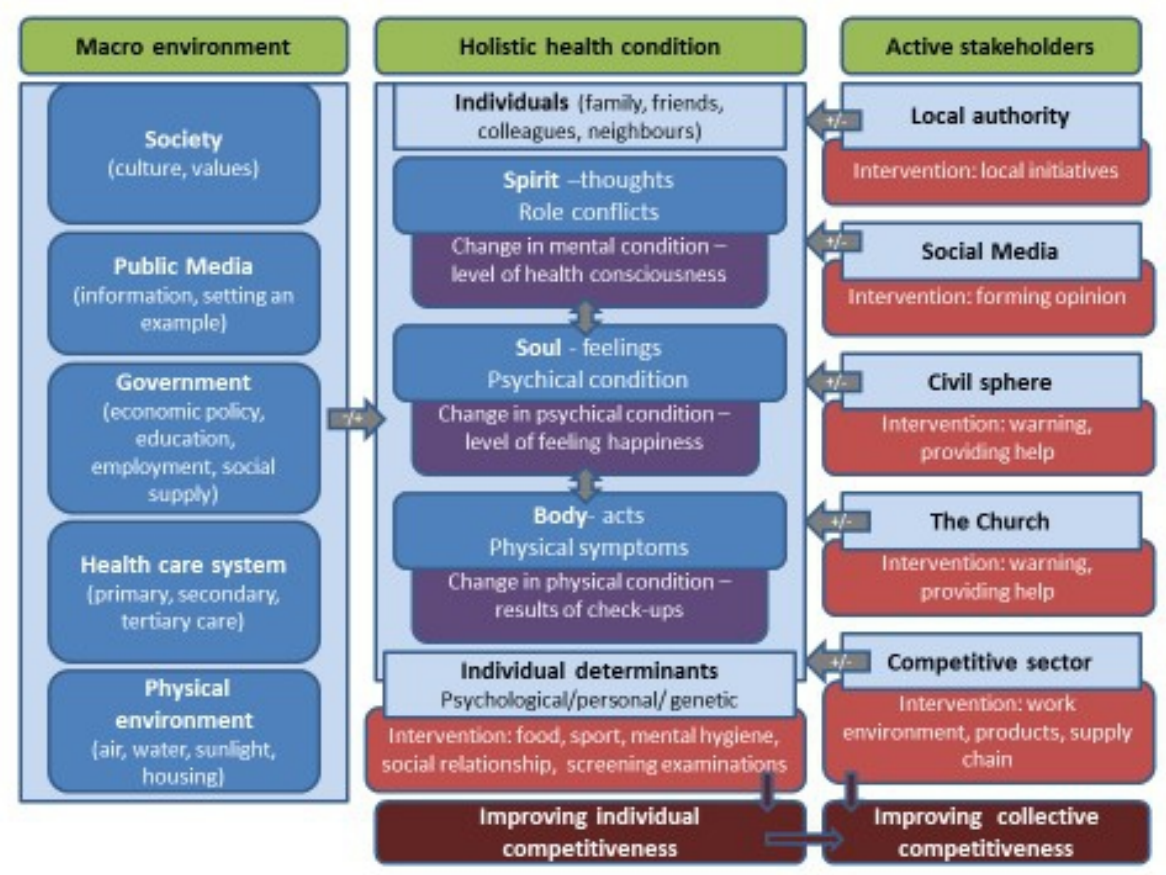

Source: Our research

\section{Conclusion}

Health is an important and what is more the central element of sustainable development. Considering the importance of health, the aim of our research was to establish the holistic health conscious model which encourages sustainable development. The holistic health conscious model means a model which includes the physical, psychical and mental health of the individual. Besides the responsibility of the individual it considers the effects coming from the surrounding environment and also considers the intervening active stakeholders furthermore it integrates the aspect of sustainable development.

The interview with experts of health revealed that it is a good idea to modify our original model. On the one hand it is worthwhile to involve the Church into the active stakeholders because it can have a great role, particularly in preserving mental health. Other individuals who affect the 
individual got into a contracted category despite the previous model. Within state activities education got the first place because of its significant effect on health. Examining the responsibility of the individual and the competitive sector the roles got the first place and not the activities. Based on the result of our research we modified our original model.

Our current empirical research has also pointed out that it is worthwhile to examine further the connections between the elements of the model and to extend the research to the detailed examination of the roles of certain active stakeholders. Additionally, besides the further development of the model we intend to examine one of the largest active stakeholders that is the company sphere. Our goal is to analyse with content analysis the practice of international and national companies with the largest sales revenue encouraging health consciousness, based on their sustainabilty reports and their homepage information. Furthermore, we would like to show international and national best practice examples which might encourage health consciousness, health development contributing to carrying out the goals of sustainable development. The research can become complete with the detailed analysis of further elements of the model.

\section{References:}

Bagdy, E. (2010): Vitalitásgenerátorok, LAM (Lege Artis Medicinae), 20. évfolyam, 1. szám, pp 6-7.

Bagdy, E. (2015): Beszélgetés Dr. Bagdy Emőkével a boldogságról, Jobb Veled a Világ Alapítvány. http://jobbveledavilag.hu/beszelgetes-drbagdyemokevel-a-boldogsagrol Downloaded: 2016. 06.17.

Csepeli, Gy. (2014): Szociálpszichológia mindenkiben. Kossuth Kiadó, Budapest. ISBN: 9789630976169

Dahlke, R. (2011): A lélek nyelve: a betegség, M-Érték Kiadó, Budapest. ISBN: 9786155113277

Emberi Erőforrások Minisztériuma: „Egészséges Magyarország 2014-2020” Egészségügyi Ágazati

Stratégia. Tervezet.http://www.kormany.hu/download/e/a4/30000/Eg\%C3\%A9szs\%C3 \%A9ges_Magyarorsz\%C3\%A1g_e\%C3\%BC_strat\%C3\%A9gia_.pdf

Downloaded: 2016. 06.17.

Every Women Every Child (2015): The Central Role of Health in the Post2015 Sustainable Development Agenda. http://www.everywomaneverychild.org/images/Health_in_the_SDGs_v10_6 April15_2.pdf Downloaded: 2016.06.17.

Frasheri, E. \& Dhamo, E. (2016): Factors That Influences Mental Health Policy In Albania. European Scientific Journal May 2016 edition vol.12, No.14, pp 175-184. doi: 10.19044/esj.2016.v12n14p175

Hidvégi P., Kopkáné Plachy J., \& Müller A. (2015): Az egészséges életmód. 
EKF Líceum Kiadó, Eger. ISBN 978-615-5297-32-8. http://unieger.hu/public/uploads/az-egeszseges-eletmod_55bf8f5ac2847.pdf Downloaded: 2016. 06.17.

Idike, A. N. (2014): Local Government and Sustainable National Development In Nigeria. European Scientific Journal September 2014 edition vol.10, No.25.

pp.161-170. http://eujournal.org/index.php/esj/article/view/4270/4092

Downloaded: 2016.06.17.

Kollányi, Zs. (2013): A gazdasági fejlődés és az egészségi állapot elméleti összefüggései. Egészségügyi Gazdasági Szemle. 51. évfolyam 1. szám, 2013. április. 37-44. http://www.weborvos.hu/adat/files/2013_majus/egsz1.pdf Downloaded: 2016. 06.17.

Kopp, M. \& Martos, T. (2011): A magyarországi gazdasági növekedés és a társadalmi jóllét, életminıség viszonya. http://ess.tk.mta.hu/wpcontent/uploads/2013/04/kopp_gazdasagi_novekedes.pdf Downloaded: 2016. 06.17.

McKinley, C.J. (2014): Information seeking. In: Thompson, T. L. (ed) (2014): Encyclopedia of Health Communication. SAGE Publications. ISBN 978-1-4522-5875-1.

Nagy, L. \& Barabás, K. (2011): Az egészségmüveltség és egészségmagatartás diagnosztikus mérésének lehetőségei, In: Csapó B. \& Zsolnai A. (szerk.) Kognitív és affektív fejlődési folyamatok diagnosztikus értékelésének lehetőségei az iskola kezdő szakaszában. Budapest: Tankönyvkiadó, 2011. pp. 173-224.

Nemzeti Egészségfejlesztési Intézet (2015): Egészségjelentés2015, Budapest.

http://www.egeszseg.hu/szakmai_oldalak/assets/files/news/egeszsegjelentes2015.pdf Downloaded: 2016. 06.17.

Newsom, J.T., McFarland, B.H., Kaplan, M.S., Huguet, N., Zani, B. (2005). The health consciousness myth. Implications of the near independence of major health behaviors in the North American population. The Journals of Gerontology, 60(6), 304-312.

Pikó, B. (2006): Lelki egészség a modern társadalomban. Akadémia Kiadó, Budapest.

Stokes, D. \& Bergin, R. (2006): Methodology Or 'Methodolatry'? An Evaluation Of Focus Groups And Depth Interviews. Qualitative Market Research: An International Journal, Vol. 9, No.2, pp 26-36.

Sustainable Development Knowledge Platform (2015): Sustainable Development Goals (SDGs) https://sustainabledevelopment.un.org/sdgs Downloaded: 2016. 05. 30.

Sustainable Development Solutions Network (2014): Health in the Framework of Sustainable Development. Technical Report for the Post-2015 
Development Agenda. 18 February 2014. http://unsdsn.org/wpcontent/uploads/2014/02/Health-For-All-Report.pdf.Downloaded: 2016. 01. 18.

Szántó, Á. (2008): Egészségpiac és egészségtudatosság - vásárlói döntést befolyásoló tényezők marketing szemléletü vizsgálata, PhD. Értekezés, Miskolci Egyetem Gazdaságtudományi Kar „Vállalkozáselmélet És Gyakorlat” Doktori Iskolája

Szolnoki, B. \& Berényi, L. (2016): A munkahelyi egészségfejlesztés szükségessége és lehetőségei. Gradus Vol 3, No 1 (2016) 495-500. http://gradus.kefo.hu/index.php/gradus/article/view/311/328 Downloaded: 2016. 06.17.

UN System Task Team on the Post-2015 UN Development Agenda (2012): Health in the post-2015 UN development agenda. Thematic Think Piece UNAIDS, UNICEF, UNFPA, WHO. May 2012. http://www.un.org/millenniumgoals/pdf/Think\%20Pieces/8_health.pdf Downloaded: 2016. 01. 18.

United Nations General Assembly (2012): The Future We Want. Resolution adopted by the General Assembly on 27 July 2012. http://www.un.org/ga/search/view_doc.asp?symbol=A/RES/66/288\&Lang=E Downloaded: 2016. 01. 18.

United Nations General Assembly (2015): Transforming our world: the 2030 Agenda for Sustainable Development. Resolution adopted by the General Assembly on $25 \quad 2015$. http://www.un.org/ga/search/view_doc.asp?symbol=A/RES/70/1\&Lang=E Downloaded: 2016. 01. 10.

United Nations (1972): Declaration of the United Nations Conference on the Human Environment.

1972. http://www.unep.org/documents.multilingual/default.asp?documentid=97\&ar ticleid=1503. Downloaded: 2016. 01. 18.

United Nations (1992): Rio Declaration on Environment and Development. 1992.

http://www.unep.org/documents.multilingual/default.asp?documentid=78\&ar ticleid=1163 Downloaded: 2016. 01. 18.

Walter, S. (2016): Holistic Health. http://ahha.org/selfhelp-articles/holistichealth/ Downloaded: 2016. 06.17.

World Commission on Environment and Development (1987): Our Common Future. 1987.http://www.un-documents.net/our-common-future.pdf Downloaded: 2016. 01. 18.

World Health Organization (1948): WHO definition of Health. 1948. www.who.int/about/definition/en/print.html. Downloaded: 2016. 01. 18.

World Health Organization (2016): World Summit on Sustainable Development. http://www.who.int/wssd/en/ Downloaded: 2016. 01. 18. 